\title{
Brevundimonas mediterranea sp. nov., a non-stalked species from the Mediterranean Sea
}

Correspondence

Wolf-Rainer Abraham

wab@gbf.de

\author{
Ingo Fritz, ${ }^{1}$ Carsten Strömpl, ${ }^{2}$ Denis I. Nikitin, ${ }^{3}$ A. M. Lysenko ${ }^{3}$ \\ and Wolf-Rainer Abraham ${ }^{2}$ \\ ${ }^{1}$ Max-Planck-Institute for Molecular Genetics, Department of Vertebrate Genomics, \\ Ihnestraße 73, 14195 Berlin, Germany \\ ${ }^{2}$ GBF - National Research Center for Biotechnology, Division of Microbiology, \\ Mascheroder Weg 1, D-38124 Braunschweig, Germany \\ ${ }^{3}$ Institute of Microbiology, Russian Academy of Sciences, Prospect 60-Letiya Octyabrya 7, \\ korp 2, Moscow 117811, Russia
}

\begin{abstract}
Six strains of Gram-negative, rod-shaped, non-spore-forming bacteria were isolated from the Mediterranean Sea. 16S rRNA gene sequence analysis indicated that the strains were affiliated within the alphaproteobacterial genus Brevundimonas, with Brevundimonas intermedia (99.4\%) and Brevundimonas vesicularis (99.2\%) as their closest relatives. This affiliation was supported by chemotaxonomic data (major polar lipids: phosphatidyl diacylglycerol, sulfoquinovosyl diacylglycerol and phosphatidyl glucopyranosyl diacylglycerol; major fatty acids: $\left.\mathrm{C}_{18: 1}, \mathrm{C}_{16: 0}, \mathrm{C}_{16: 1}, \mathrm{C}_{15: 0}, \mathrm{C}_{17: 1} \omega 8 c, 11-\mathrm{Me}_{18: 1} \omega 5 t\right)$. The results of DNA-DNA hybridization and physiological and biochemical tests allowed genotypic and phenotypic differentiation of the strains from all recognized Brevundimonas species. The strains therefore represent a novel species, for which the name Brevundimonas mediterranea sp. nov. is

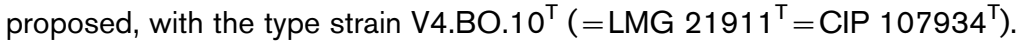

Two species originally described as Pseudomonas diminuta and Pseudomonas vesicularis were reclassified by Segers et al. (1994) into a new genus Brevundimonas with Brevundimonas diminuta as the type species of the genus. In 1999 several species were transferred from the genus Caulobacter to Brevundimonas and the description of the genus Brevundimonas was emended (Abraham et al., 1999). Brevundimonas species are characterized and differentiated from Caulobacter species by the presence of certain glycoand polar lipids, outer-membrane proteins and an increased salt tolerance, but members of the genus show diverse cell morphologies and substrate specificities. Although some marine Brevundimonas strains have been described (Stahl et al., 1992; Yokoyama et al., 1996; Abraham et al., 2002),

Published online ahead of print on 5 November 2004 as DOI 10.1099/ ijs.0.02852-0.

Abbreviations: LMW-RNA, low-molecular-mass RNAs (tRNAs and rRNAs); OTU, operational taxonomic unit; PGL, phosphatidyl glucopyranosyl diacylglycerol; RAPD, randomly amplified polymorphic DNA.

The GenBank/EMBL/DDBJ accession numbers for the 16S rRNA gene sequences of strains V4.BO.07, V4.BO.10 ${ }^{\top}$, LMG 9567t1, LMG 11070, LMG 9564, V4.BO.05, V4.BO.22, V4.BO.18, V4.BE.56, V4.BO.27, V4.BE.49 and V4.BP.05 are AJ227800, AJ227801, AJ244647-AJ244649 and AJ244704-AJ244710.

Strain details, transmission electron micrographs, protein profiles and RAPD profiles are available as supplementary material in IJSEM Online. no marine Brevundimonas species has been named to date. Here we describe six strains isolated from marine water samples, which we propose are representatives of a novel species, Brevundimonas mediterranea sp. nov.

\section{Sampling}

Marine water samples were taken aboard the ship Thetys II (Institute National des Sciences de l'Univers INSU - CNRS/ France) at two stations located in the north-western basin of the Mediterranean Sea on a transect between Nice and Corsica. Stations S1 [5.5 nautical miles (about $10 \mathrm{~km}$ ) from the coast, nautical coordinates $\left.43^{\circ} 37^{\prime} 48^{\prime \prime} \mathrm{N} 7^{\circ} 26^{\prime} 06^{\prime \prime} \mathrm{E}\right]$ and station S2 28 nautical miles (about $52 \mathrm{~km}$ ) from the coast, nautical coordinates $\left.43^{\circ} 25^{\prime} 00^{\prime \prime} \mathrm{N} 7^{\circ} 52^{\prime} 00^{\prime \prime} \mathrm{E}\right]$ were sampled in early April 1995. Samples were collected with 12 litre Niskin bottles during the early afternoon and were stored in $\mathrm{HCl}$-washed polycarbonate tanks until return to the institute. Plating was performed in triplicate either directly on Difco marine broth (MB) agar (representing the total biocoenosis) or using either the filtrate (representing the free-living biocoenosis) or the resuspended residue (representing the particle-bound biocoenosis) from $1 \mu \mathrm{m}$ Nucleopore-filtered marine water samples (Fritz, 2000). After 2 weeks of dark incubation at ambient temperature, plate counts were performed and bacterial colonies were isolated. 


\section{Isolation and morphological diagnosis}

Plates occasionally showed an abundance of a distinct type of bacteria with unique colony morphology. Bacterial colonies were cream-white in colour with a central brownish spot and had a slimy consistency; depending on age, colonies measured between 2 and $8 \mathrm{~mm}$ in diameter and contributed to more than $50 \%$ of all colony-forming units in all triplicates of some investigated water samples (Fritz, 2000). Colony-forming units with this distinct, highly characteristic morphology were observed in water samples from both stations, from both free-living and particlebound biocoenosis and from various depths. Six strains (V4.BE.49, V4.BE.56, V4.BO.10 ${ }^{\mathrm{T}}$, V4.BO.18, V4.BO.22 and V4.BO.27) with the described colony morphology originating from water samples from both stations and various depths were purified to macroscopic and microscopic homogeneity (see Supplementary Table A for details of their properties, available in IJSEM Online). Microscopically, the cells consisted of flexible, slightly bent long rods with a length of $1 \cdot 5-4 \mu \mathrm{m}$ and a diameter of $0 \cdot 5-1 \mu \mathrm{m}$ (Supplementary Fig. A). These six strains are hereafter referred to as operational taxonomic unit (OTU) H (Fritz, 2000).

\section{$16 S$ rRNA gene sequencing}

16S rRNA gene sequence analysis, conducted as described by Abraham et al. (1999), showed that the six OTU H strains were very similar, with sequence similarities exceeding $99 \cdot 8 \%$, and that they formed a distinct lineage within the genus Brevundimonas (Fig. 1). The closest recognized relatives of strain $\mathrm{V} 4 . \mathrm{BO} .10^{\mathrm{T}}$ were the unpigmented prosthecate strain Brevundimonas intermedia ATCC $15262^{\mathrm{T}}$ and the red-pigmented Brevundimonas vesicularis LMG $2350^{\mathrm{T}}$, with respective sequence similarities of $99 \cdot 4$ and $99.2 \%$. Slightly more distantly related were Brevundimonas aurantiaca DSM $4731^{\mathrm{T}}(98.9 \%)$ and the recently discovered Brevundimonas nasdae GTC $1043^{\mathrm{T}}$ (99.0\%) (Li et al., 2004). To provide further detail of the taxonomic relations within the genus Brevundimonas, the 16S rRNA gene sequences of three hitherto phylogenetically unaffiliated Brevundimonas strains, LMG 9564, LMG 9567t1 and LMG 11070 (Segers et al., 1994), were determined. Among these strains, the unpigmented Brevundimonas sp. LMG 11070 appeared to be a close relative of OTU $\mathrm{H}$, whereas the red-pigmented strains LMG 9564 and LMG 9567t1 showed close phylogenetic relationships to $B$. aurantiaca and $B$. vesicularis, respectively. In addition, strain LMG 19834, characterized by Mergaert et al. (2001), showed a close relationship to OTU H. Thus OTU H, LMG 11070 and LMG 19834 formed a monophyletic cluster within the genus Brevundimonas. This topology was supported by maximum parsimony and maximum likelihood and in $93 \%$ of the neighbour-joining bootstrap calculations. Within this cluster, strain V4.BO.18 formed a subcluster together with strains LMG 11070 and LMG 19834, due to a 3 nt exchange (i.e. $0 \cdot 2 \%$ ) common to these three strains in the 1416 bp sequence investigated.

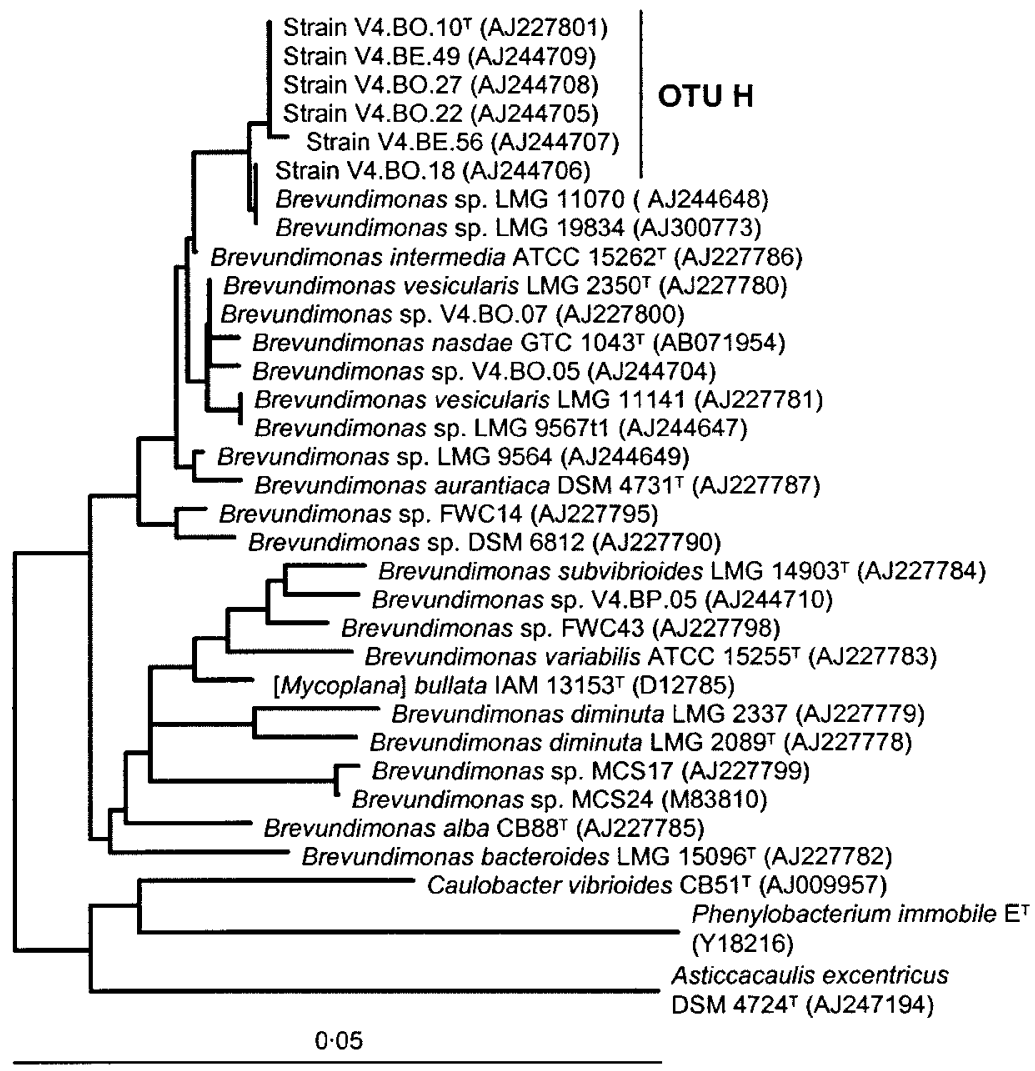

Fig. 1. Similarity dendrogram based on the comparison of $16 \mathrm{~S}$ rRNA gene sequences. The dendrogram was calculated with the method of Fitch \& Margoliash (1967) after distance correction as described by Jukes \& Cantor (1969) and as implemented in the ARB (MacOSX port) and PHYLIP program packages (Felsenstein, 1989; Hines \& DyallSmith, 2003; Ludwig et al., 2004), respectively. To compensate for multiple nucleotide substitutions, only columns at which all nucleotides were unambiguously determined and one nucleotide had an abundance of $50 \%$ or more were included in the calculation. A nucleotide sequence stretch spanning $21 \mathrm{nt}$ between the Escherichia coli homologous positions 1256 and 1278 , which is present in the genus Caulobacter but is missing in the genus Brevundimonas (Abraham et al., 1999; Anzai et al., 2000; Fritz, 2000), was been included in the calculation. Additional dendrograms calculated with maximum-likelihood and neighbourjoining bootstrap analyses (1000 bootstraps) proved the robustness of the presented overall tree topology. 
(a)

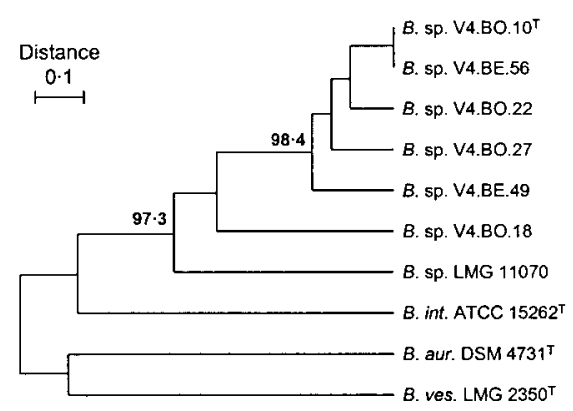

(b)

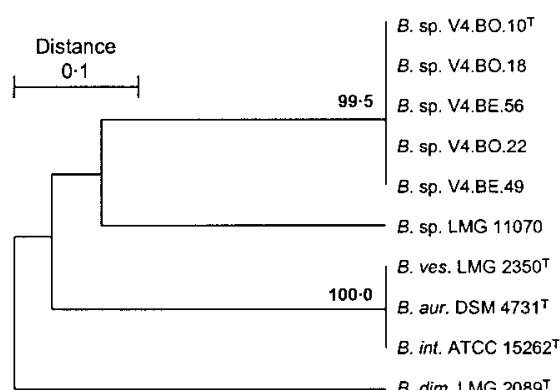

(c)

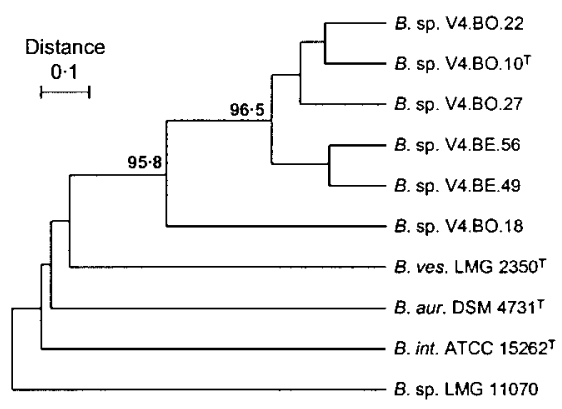

Fig. 2. Similarity dendrograms from protein fingerprints (a), LMW-RNA profiles (b) and RAPD-PCR fingerprints (c). Starting from a digital file of the scanned gel, bands were manually assigned using the program RFLPSCAN 3.0 (Scanalytics). After applying appropriate band tolerances to correct for imperfections resulting from the electrophoresis process in individual lanes, a binary representation of presence/absence patterns of matched gel bands was constructed. Further evaluation was by use of the program packages TREECON 1.15 (Van de Peer \& De Wachter, 1994) and PHYLIP 3.6 (Felsenstein, 2004). A distance matrix was calculated according to the formula $D_{x y}=\left(N_{x}+N_{y}\right) /\left(N_{x}+N_{y}+N_{x y}\right)$ (Link et al., 1995), where $D_{x y}$ is the distance between two pairwise-compared lanes $x$ and $y, N_{x}$ is the number of bands present in lane $x$ but not in lane $y, N_{y}$ is the number of bands present in $y$ but not in $x$ and $N_{x y}$ is the number of bands present in both lanes. A total of 1000 bootstraps was calculated. The tree construction method was UPGMA. Only bootstrap values above than $90 \%$ are shown. Abbreviations: B. aur., Brevundimonas aurantiaca; B. dim., Brevundimonas diminuta; B. int., Brevundimonas intermedia; B. ves., Brevundimonas vesicularis.

\section{Fingerprinting}

Fingerprinting data targeted at the protein, RNA and genomic DNA levels supported the suggestion that OTU H was a homogeneous taxonomic entity. As shown in Fig. 2, UPGMA clustering of binary presence/absence patterns based on matched gel bands reliably distinguished OTU $\mathrm{H}$ strains from their closest recognized relatives using all investigated fingerprint techniques.

PAGE of whole-cell proteins revealed that all OTU $\mathrm{H}$ strains with the exception of V4.BO.18 possessed indistinguishable protein profiles (Fig. 2a; Supplementary Fig. B). The profiles of V4.BO.18 and LMG 11070 differed slightly from the other protein profiles of OTU $\mathrm{H}$ in the region between 75 and $100 \mathrm{kDa}$. By contrast, the protein profiles from B. aurantiaca DSM $4731^{\mathrm{T}}$, B. vesicularis LMG $2350^{\mathrm{T}}$ and $B$. intermedia ATCC $15262^{\mathrm{T}}$ were more heterogeneous and appeared clearly different from those of the OTU H strains.

As shown by Fritz (2000), all six OTU H strains possessed identical low-molecular-mass RNA (LMW-RNA) profiles, which differed at least in the size of one distinct band to all recognized Brevundimonas species. Höfle (1998) indicated that identical LMW-RNA profiles point to a degree of relatedness at the species level. Indeed, the type strains of $B$. vesicularis, $B$. intermedia and $B$. aurantiaca shared an identical LMW-RNA profile [Fig. 2b; see scanned gel in Fritz (2000), p. 126], but were not related at the species level, as shown by DNA-DNA hybridization data (Table 1) and various other approaches (Abraham et al., 1999; Li et al., 2004). This demonstrates that LMW-RNA profiles can be used to differentiate Brevundimonas strains above species but below the genus level. Consequently, LMW-RNA profile analysis supports the view of an affiliation of OTU $\mathrm{H}$ within a distinct Brevundimonas species (Fritz, 2000). The LMW-RNA profile of strain LMG 11070 differed from that of the OTU H strains.

Randomly amplified polymorphic DNA (RAPD) fingerprints, targeted at the clonal structure below species level, were conducted as described by Ziemke et al. (1997). The monophyly of OTU H was supported in $95.8 \%$ of 1000 bootstrap analyses (Fig. 2c; Supplementary Fig. C). However, the RAPD fingerprints of OTU $\mathrm{H}$ were similar but not identical. Instead, OTU H could be differentiated into three RAPD fingerprint types. Type 1 consisted of three strains

Table 1. Genomic DNA-DNA hybridization values (\%) for type strains from selected Brevundimonas species

\begin{tabular}{|lrrrc|}
\hline Strain & $\mathbf{1}$ & $\mathbf{2}$ & $\mathbf{3}$ & $\mathbf{4}$ \\
\hline 1. B. vesicularis LMG $2350^{\mathrm{T}}$ & 100 & & & \\
2. B. aurantiaca DSM $4731^{\mathrm{T}}$ & 35 & 100 & & \\
3. V4.BO.10 & 33 & 33 & 100 & \\
4. B. ${\text { intermedia ATCC } 15262^{\mathrm{T}}}$ & $\mathrm{ND}^{*}$ & $33 \dagger$ & 27 & $100 \dagger$ \\
\hline
\end{tabular}

${ }^{*}$ A DNA-DNA hybridization value ('stringent conditions') of $34 \cdot 4 \%$ was reported by Li et al. (2004). The other hybridization values measured by Li et al. (2004) under stringent conditions are in good agreement with the corresponding hybridization values determined in our study.

$\nmid$ Data taken from Abraham et al. (1999). 
isolated from the oligotrophic station, strains V4.BO.10 ${ }^{\mathrm{T}}$, V4.BO.22 and V4.BO.27, but not strain V4.BO.18. Type 2 consisted of both strains from the eutrophic station, V4.BE.49 and V4.BE.56. V4.BO.18 had a unique RAPD fingerprint type. Thus OTU H consisted of three clonal lineages. Strain LMG 11070 could not be affiliated with any of the three fingerprint types.

\section{G+C content, genome size and DNA-DNA hybridization}

The DNA G + C contents of OTU H ranged between $67 \cdot 1$ and $67.5 \mathrm{~mol} \%$ (Supplementary Table A). This is slightly higher than the $\mathrm{G}+\mathrm{C}$ contents measured for $B$. intermedia ATCC $15262^{\mathrm{T}}(66 \cdot 1 \mathrm{~mol} \%), B$. vesicularis LMG $2350^{\mathrm{T}}$ $(66 \cdot 2 \mathrm{~mol} \%)$ and B. aurantiaca DSM $4731^{\mathrm{T}}(65 \cdot 6 \mathrm{~mol} \%)$. For strain LMG 11070, Segers et al. (1994) determined a $\mathrm{G}+\mathrm{C}$ content of $67 \cdot 0 \mathrm{~mol} \%$. The genome size of strain V4.BO. $10^{\mathrm{T}}$, as determined by the method of Gillis et al. (1970), was $2.4 \times 10^{9} \mathrm{Da}$. Similar genome sizes were determined for $B$. intermedia ATCC $15262^{\mathrm{T}}\left(2 \cdot 2 \times 10^{9} \mathrm{Da}\right), B$. vesicularis LMG $2350^{\mathrm{T}}\left(2 \cdot 3 \times 10^{9} \mathrm{Da}\right)$ and $B$. aurantiaca DSM $4731^{\mathrm{T}}\left(2 \cdot 4 \times 10^{9} \mathrm{Da}\right)$. DNA-DNA hybridization data are shown in Table 1. For strain V4.BO. $10^{\mathrm{T}}$, no DNA relatedness exceeding $33 \%$ was measured, which is well below the generally accepted value of $70 \%$ for intraspecies strains (Wayne et al., 1987).

\section{Lipid analysis}

For OTU H, fatty acids have been reported to be similar to those of $B$. intermedia and the polar lipids were phosphatidyl diacylglycerol $(720,734,746,748,760,762$, 774 and $788 \mathrm{Da}$ ), sulfoquinovosyl diacylglycerol (820 and $834 \mathrm{Da})$ and phosphatidyl glucopyranosyl diacylglycerol (PGL; 1411, 1413, 1425, 1427, 1439, 1453 Da) (Abraham et al., 1997). The cellular fatty acids of strain V4.BO.10 ${ }^{\mathrm{T}}$ comprised $\mathrm{C}_{14: 0}(0.6 \%), \mathrm{C}_{15: 0}(5 \cdot 4 \%), \quad 3-\mathrm{OH}-\mathrm{C}_{12: 0}$ $(2 \cdot 0 \%), \mathrm{C}_{16: 0}(16 \cdot 1 \%), \mathrm{C}_{17: 0}(6 \cdot 1 \%), \mathrm{C}_{18: 0}(0 \cdot 9 \%)$, $\mathrm{C}_{16: 1}(8 \cdot 4 \%), \mathrm{C}_{17: 1} \omega 6 c(7 \cdot 8 \%), \mathrm{C}_{17: 1} \omega 8 c(9 \cdot 9 \%), \mathrm{C}_{18: 1}$ $(36 \cdot 7 \%), 11-\mathrm{Me}-\mathrm{C}_{18: 1} \omega 5 t(4 \cdot 2 \%)$ and ECL $17.897(1 \cdot 6 \%)$, similar to those of Brevundimonas sp. LMG 11070, and with larger amounts of $\mathrm{C}_{15: 0}$ and $\mathrm{C}_{17: 1} \omega 8 \mathrm{c}$ and smaller amounts of $\mathrm{C}_{18: 1}$ compared with $B$. intermedia and B. vesicularis (Abraham et al., 1997). OTU $\mathrm{H}$ differed from the recently described B. nasdae (Li et al., 2004) by the presence of considerable amounts of $\mathrm{C}_{15 \text { : } 0}$, larger amounts of summed feature 4 fatty acids, the presence of fatty acid ECL 17.897, larger amounts of $11-\mathrm{Me}-\mathrm{C}_{18: 1} \omega 5 t$ and summed feature 7 fatty acids and the lack of $\mathrm{C}_{19: 0}$ cyclo $\omega 8 c$.

\section{Substrate utilization}

Good growth of the OTU H strains was obtained at $30^{\circ} \mathrm{C}$ and $\mathrm{NaCl}$ concentrations between 1 and $3 \%(\mathrm{w} / \mathrm{v})$. Further details are given in the species description. Strain LMG 11070 did not tolerate $\mathrm{NaCl}$ concentrations above 1\% $(\mathrm{w} / \mathrm{v})$. No nitrogen fixation was detected, as tested by growth experiments in Burk's nitrogen-free medium (Smibert \& Krieg, 1981), which was adjusted to an $\mathrm{NaCl}$ concentration of $3 \%(\mathrm{w} / \mathrm{v})$.

The results from substrate specificity tests, as determined by API galleries (bioMérieux) and from Biolog substrate utilization tests, are given in detail in the species description. Criteria for differentiation on the basis of substrate utilization patterns between the OTU H strains as well as closely related Brevundimonas species and isolates are given in Table 2.

As revealed by API ZYM tests, the OTU H strains exhibited similar enzyme activity patterns (see Table 3 and the species description). The strains could be differentiated from $B$. vesicularis by the presence of $\beta$-glucosidase activity and from $B$. intermedia by the lack of chymotrypsin and $\beta$-galactosidase activity.

\section{Conclusions and discussion}

The data presented here suggest a close affiliation of the genetically and phenetically similar six OTU $\mathrm{H}$ strains at the species level. As revealed by $16 \mathrm{~S}$ rRNA gene sequence data, RAPD and protein fingerprints, strain V4.BO.18 differed slightly from all other OTU H strains, but phenotypic data did not permit a clear-cut distinction of this strain above the species level. Consequently, we propose to affiliate strain V4.BO.18 with the remaining OTU H strains at the species level. The taxonomic status of strain LMG 11070, however, remains unclear. Strain LMG 11070 is similar to OTU $\mathrm{H}$ with respect to protein fingerprints, cellular lipid content and $16 \mathrm{~S}$ rRNA gene sequences. However, LMG 11070 differs from the OTU $\mathrm{H}$ strains in a number of phenotypic traits, including LMW-RNA profiles, the lack of tolerance of $\mathrm{NaCl}$ concentrations above $1 \%$ and substrate utilization patterns (Table 2). Further investigations are required to clarify the taxonomic status of this strain. With regard to strain LMG 19834, Mergaert et al. (2001) reported its inability to reduce nitrate to $\mathrm{N}_{2}$ and that, in contrast to the OTU H strains, LMG 19834 formed stalks. As we did not investigate this strain in detail, we cannot determine whether strain LMG 19834 and OTU H are related at the species level.

Although generally regarded as non-marine bacteria, reports on Brevundimonas strains isolated from marine habitats have accumulated (Stahl et al., 1992; Yokoyama et al., 1996; Abraham et al., 2002). Two marine Brevundimonas sp. strains, MCS 17 and MCS 24 (Stahl et al., 1992; Abraham et al., 2002), for which 16S rRNA gene sequence data have been published, showed relatively distant phylogenetic relationships (96.1-96.7 \% similarity) with OTU H (Abraham et al., 1999) (Fig. 2). During sampling in the Mediterranean Sea, from a total of 227 isolated strains, three further Brevundimonas strains were isolated (Fritz, 2000). The redpigmented strains V4.BO.05 and V4.BO.07 (designated OTU $\mathrm{H}^{\prime}$ in Fritz, 2000) were closely related to B. vesicularis, whereas the brown-pigmented strain V4.BP.05 (designated 
Table 2. Differentiation of selected Brevundimonas species and strains according to substrate utilization patterns and pigmentation

Strains were cultivated in a mineral salts medium with addition of trace elements and vitamins, but without any carbon and energy source. Substrate utilization patterns were determined with the API 20NE, API 50CH and API Biotype 100 galleries (bioMérieux). Data from Biolog analyses are not included. +, Detected in all strains; -, not detected in any strain; + - detected in some strains, including the type strain; - +, detected in some strains, excluding the type strain; ND, not determined. Data for B. vesicularis and strain LMG 11070 were taken from Segers et al. (1994).

\begin{tabular}{|c|c|c|c|c|}
\hline Characteristic & OTU H & LMG 11070 & B. intermedia & B. vesicularis \\
\hline Pigmentation & - & - & - & +- \\
\hline D-Galactose & -+ & + & + & + \\
\hline$\beta$-Hydroxybutyrate & +- & ND & + & + \\
\hline Fumarate & +- & ND & + & +- \\
\hline $\mathrm{L}(-)$-Malate & +- & ND & + & +- \\
\hline Maltotriose & +- & ND & + & ND \\
\hline L-Proline & +- & ND & + & + \\
\hline Cellobiose & + & ND & + & - \\
\hline Salicin & + & + & + & - \\
\hline Rhamnose & -+ & ND & - & -+ \\
\hline L-Serine & -+ & ND & - & -+ \\
\hline Adipate & -+ & - & + & - \\
\hline L-Alanine & -+ & - & + & - \\
\hline D-Fructose & + & - & + & - \\
\hline Gentiobiose & + & - & + & - \\
\hline Propionate & + & - & + & - \\
\hline Arbutin & + & + & - & - \\
\hline Amygdalin & + & - & - & - \\
\hline L-Arabinose & +- & - & - & - \\
\hline Trehalose & + & - & - & - \\
\hline Turanose & +- & - & - & - \\
\hline Caprate & - & + & - & - \\
\hline D-Arabinose & - & - & + & - \\
\hline Lactose & - & - & + & - \\
\hline D-Mannose & - & - & + & - \\
\hline D-Xylose & - & - & + & - \\
\hline L-Aspartate & - & ND & + & -+ \\
\hline Galacturonate & - & ND & + & - \\
\hline D-Glucosamine & - & ND & + & - \\
\hline Lactulose & - & ND & + & - \\
\hline Melibiose & - & ND & + & - \\
\hline Methyl $\beta$-glucopyranoside & - & $\mathrm{ND}$ & + & - \\
\hline D-Alanine & - & ND & - & -+ \\
\hline
\end{tabular}

OTU $\mathrm{H}^{*}$ in Fritz, 2000) was similar but not identical to Brevundimonas subvibrioides. However, as revealed by plate counts, no abundance of colony-forming units with similar morphologies to these strains was detected in any of the water samples investigated by Fritz (2000). Analyses of a clone library from excised DGGE bands derived from RNA extracts from the Mediterranean water samples revealed the presence of a clone with a partial 16S rRNA gene sequence similar to Brevundimonas alba (I. Fritz, unpublished, accession number AJ508416), suggesting an abundance of further Brevundimonas species in marine water samples.
Based on the data presented, we propose that the six OTU H strains cannot be affiliated within any recognized Brevundimonas species. The closest recognized relative of the OTU $\mathrm{H}$ strains is $B$. intermedia, which differs on the basis of morphology, genome size, presence of chymotrypsin and $\beta$-galactosidase activity and absence of PGLs of $1411 \mathrm{Da}$ (Abraham et al., 1997). The OTU H strains differ from $B$. vesicularis by having thicker cells, the presence of $\beta$-glucosidase, smaller amounts of $\mathrm{C}_{15: 0}, \mathrm{C}_{16: 1}$ and $\mathrm{C}_{17: 1} \omega 8$, but larger amounts of $\mathrm{C}_{18: 1}$, the presence of phosphatidylglycerols of $720,734,746,760$ and $788 \mathrm{Da}$ 
Table 3. Enzyme activity patterns of selected Brevundimonas species and strains

W, Weak activity; otherwise, enzyme activities are scored as in Table 2. Data for strain LMG 11070 and B. vesicularis were taken from Segers et al. (1994).

\begin{tabular}{|lcccc|}
\hline Enzyme & OTU H & LMG 11070 & B. intermedia & B. vesicularis \\
\hline$\alpha$-Glucosidase & $\mathrm{W}^{\star}$ & + & + & + \\
$\beta$-Glucosidase & $+^{*}$ & + & + & - \\
Naphthol-AS-BI-phosphohydrolase & + & $\mathrm{ND}$ & + & $\mathrm{ND}$ \\
Valine arylamidase & + & $\mathrm{ND}$ & + & + \\
Chymotrypsin & - & $\mathrm{ND}$ & + & - \\
$\beta$-Galactosidase & - & - & + & - \\
\hline
\end{tabular}

${ }^{\star}$ Negative for strain V4.BO.18.

and the presence of PGL of $1411 \mathrm{Da}$. OTU H can be distinguished from the recently described $B$. nasdae GTC $1043^{\mathrm{T}}$ (Li et al., 2004) by the presence of $\mathrm{C}_{15: 0}$ and ECL 17.897, larger amounts of 11-Me- $\mathrm{C}_{18: 1} \omega 5 t$ and the lack of $\mathrm{C}_{19: 0}$ cyclo $\omega 8 c$ in the cellular fatty acids, a higher $\mathrm{G}+\mathrm{C}$ content, the ability to grow at $\mathrm{NaCl}$ concentrations of $4 \%$ $(\mathrm{w} / \mathrm{v})$, the ability to utilize fructose but not succinate and $n$-capric acid as well as the presence of urease activity in some strains. Furthermore, the OTU H strains can be differentiated from their closest recognized relatives by DNA-DNA hybridization, 16S rRNA gene sequencing, LMW-RNA profile analysis, protein fingerprints and substrate utilization patterns. Therefore, we propose to include the six OTU H strains within a novel species, Brevundimonas mediterranea sp. nov., with $\mathrm{V} 4 . \mathrm{BO} .10^{\mathrm{T}}$ as the type strain.

\section{Description of Brevundimonas mediterranea sp. nov.}

Brevundimonas mediterranea (me.di.ter.ra'ne.a. N.L. fem. adj. mediterranea of the Mediterranean Sea).

The description is as that of the genus with the following additions. Colonies measure $2-5 \mathrm{~mm}$ in diameter on $\mathrm{MB}$ agar, have a soft and slimy consistency with a glistening surface and smooth margin, a slightly concave shape and are cream-white coloured with a characteristic slightly brownish spot in the centre. Pigmentation is not present. Flexible, non-stalked, occasionally bent rods with a length of $1 \cdot 5-4 \mu \mathrm{m}$ and a diameter of $0 \cdot 5-1 \cdot 0 \mu \mathrm{m}$. Some strains but not the type strain may possess a branching cell morphology.

Alkaline and acid phosphatase, esterase (C4), esterase lipase (C8), $\beta$ - and weak $\alpha$-glucosidase, leucine arylamidase, valine arylamidase and trypsin activities are always positive. Activities for the following enzymes are not detected: chymotrypsin, cystine arylamidase, $\alpha$-fucosidase, $\alpha$-galactosidase, $\beta$-galactosidase, $\beta$-glucuronidase, lipase (C14), $\alpha$-mannosidase and $\mathrm{N}$-acetylglucosaminidase. Urease activity is present in some strains but not the type strain. Gelatin is not liquefied. Aesculin is hydrolysed. As determined by API galleries, the following substrates are utilized by all strains: amygdalin, arbutin, cellobiose, D-fructose, gentiobiose, $\alpha$-D-glucose, $\beta$-hydroxybutyric acid, maltose, salicin and starch. The following substrates are used as sole carbon and energy sources by some strains including the type strain: Larabinose, fumarate, L-glutamate, DL-lactate, $\mathrm{L}(-)$-malate, maltotriose, L-proline, propionate and turanose. The following substrates were utilized by some strains but not by the type strain: adipate, L-alanine, rhamnose and L-serine. The following substrates are not utilized: $\mathrm{D}(+)$ malate, malonate, maltitol, mannitol, D-mannose, melezitose, melibiose, methyl $\alpha$-D-glucopyranoside, methyl $\alpha$-galactopyranoside, methyl $\beta$-galactopyranoside, methyl $\beta$-glucopyranoside, methyl $\alpha$-D-mannoside, methyl $\beta$ xyloside, mucate, palatinose, phenylacetate, 3-phenylpropionate, protocatechuate, putrescine, $(-)$-quinate, Draffinose, $\mathrm{D}(-)$-ribose, D-saccharate, D-sorbitol, L-sorbose, D-tagatose, $\mathrm{D}(-)$-tartrate, $\mathrm{L}(+)$-tartrate, meso-tartrate, trehalose, tricarballylate, trigonelline, tryptamine, tyrosine, L-xylitol, xylitol, D-xylose and L-xylose.

As measured by Biolog tests, Tween 40 and $\alpha$-cyclodextrin serve as electron donors for the artificial electron acceptor tetrazolium violet and thus may be metabolized by all strains. Some strains including the type strain use acetic acid, alaninamide, $\gamma$-aminobutyric acid, 2-aminoethanol, L-asparagine, 2,3-butanediol, dextrin, D-galactonic acid lactone, glycyl L-aspartic acid, glycyl L-glutamic acid, hydroxy-L-proline, methylpyruvate, monomethyl succinate, L-ornithine, L-pyroglutamic acid, sebacic acid, L-threonine and Tween 80 as electron donors. L-Alanyl glycine is utilized by some strains but not by the type strain. None of the following are used as electron donors by any strain: $\mathrm{N}$ acetyl-D-galactosamine, bromosuccinic acid, DL-carnitine, formic acid, D-glucosaminic acid, glucose 1-phosphate, glucose 6-phosphate, glucuronamide, DL- $\alpha$-glycerol phosphate, $\alpha$-hydroxybutyric acid, $\gamma$-hydroxybutyric acid, $p$-hydroxyphenylacetic acid, inosine, $\alpha$-ketobutyric acid, $\alpha$-ketoglutaric acid, $\alpha$-ketovaleric acid, L-leucine, phenylethylamine, L-phenylalanine, D-psicose, D-serine, succinamic acid, succinic acid, sucrose, thymidine, uridine and urocanic acid.

$\mathrm{NaCl}$ is not strictly required but promotes growth at 
optimal concentrations. The optimum $\mathrm{NaCl}$ concentration for growth is $1 \%(\mathrm{w} / \mathrm{v})$, with good growth at $0-3 \%$ and no growth at $6 \%$ or above. Optimal growth temperature is $30^{\circ} \mathrm{C}$. The species grows between 15 and $37^{\circ} \mathrm{C}$, but not above $42^{\circ} \mathrm{C}$. Some strains including the type strain show weak growth at $7{ }^{\circ} \mathrm{C}$. Nitrogen is not fixed. Neither nitrate nor nitrite is utilized as a terminal electron acceptor with the exception of strain V4.BO.18, which is capable of reducing nitrate to nitrite but not to nitrogen. Polar lipids are $18: 1 /$ $14: 0-, 18: 1 / 15: 0-, 18: 1 / 16: 1-, 18: 1 / 16: 0-, 18: 1 / 17: 1-$, $18: 1 / 18: 1-, 19: 1 / 16: 0-$ and $19: 1 / 18: 1-P G, 18: 1 / 17: 0-$ SQDG and PGLs of 1411, 1413, 1425, 1427, 1439 and 1453 $\mathrm{Da}$. The main fatty acids of the cellular hydrolysate are $\mathrm{C}_{18: 1}, \mathrm{C}_{16: 0}, \mathrm{C}_{16: 1}, \mathrm{C}_{15: 0}, \mathrm{C}_{17: 1} \omega 8 c, \mathrm{C}_{17: 1} \omega 6 c, \mathrm{C}_{17: 0}$ and $11-\mathrm{Me}-\mathrm{C}_{18: 1} \omega 5 t$; the main hydroxy-fatty acid is $3-\mathrm{OH}-$ $\mathrm{C}_{12: 0}$. The $\mathrm{G}+\mathrm{C}$ content is between $67 \cdot 1$ and $67 \cdot 5 \mathrm{~mol} \%$. Main ubiquinone is Q-10 (Abraham et al., 1999). DNADNA relatedness between strain V4.BO. $10^{\mathrm{T}}$ and $B$. intermedia ATCC $15262^{\mathrm{T}}$, B. vesicularis LMG $2350^{\mathrm{T}}$ and $B$. aurantiaca DSM $4731^{\mathrm{T}}$ is 27,33 and $33 \%$, respectively.

Strain V4.BO. $10^{\mathrm{T}}\left(=\mathrm{LMG} 21911^{\mathrm{T}}=\mathrm{CIP} 107934^{\mathrm{T}}\right)$ is the type strain. The strains were isolated from water samples from the western Mediterranean Sea near Nice.

\section{Acknowledgements}

The generous support of Dr Manfred Höfle is greatly appreciated. We thank Jennifer Skerra for excellent technical assistance and are indebted to Dagmar Wenderoth, Ina Buchholz and Tanja Jeschke for microbiological work, Peter Wolff for fatty acid analysis and Ruprecht Christ for measuring the CID mass spectra, Margret Krause for help with protein gel electrophoresis and Dr Heinrich Lünsdorf for electron microscopy. Thanks are due to the crew of the Thetys II and the staff of the Observatoire Océanologique de Villefranche-sur-Mer, especially Dr Gabriel Gorsky and Dr Richard Christen, for their hospitality and for support during sampling and isolation in early April 1995. Dr James Adjaye is thanked for critically reading the manuscript. The work was supported by the HGF strategy funds 'Soil functions'. Parts of this work were conducted within the Mediterranean Targeted Project (MTP)EMPS and was supported by the MAST programme of the EU, contract MAS2-CT94-0090.

\section{References}

Abraham, W.-R., Meyer, H., Lindholst, S., Vancanneyt, M. \& Smit, J. (1997). Phospho- and sulfolipids as biomarkers of Caulobacter, Brevundimonas and Hyphomonas. Syst Appl Microbiol 20, 522-539.

Abraham, W. R., Strömpl, C., Meyer, H. \& 8 other authors (1999). Phylogeny and polyphasic taxonomy of Caulobacter species. Proposal of Maricaulis gen. nov with Maricaulis maris (Poindexter) comb. nov. as the type species, and emended description of the genera Brevundimonas and Caulobacter. Int J Syst Bacteriol 49, 1053-1073.

Abraham, W.-R., Strömpl, C., Bennasar, A., Vancanneyt, M., Snauwaert, C., Swings, J., Smit, J. \& Moore, E. R. B. (2002). Phylogeny of Maricaulis Abraham et al. 1999 and proposal of Maricaulis virginensis sp. nov., Maricaulis parjimensis sp. nov., Maricaulis washingtonensis sp. nov., and Maricaulis salignorans sp. nov. Int J Evol Syst Microbiol 52, 2191-2201.

Anzai, Y., Kim, H., Park, J. Y., Wakabayashi, H. \& Oyaizu, H. (2000). Phylogenetic affiliation of the pseudomonads based on 16S rRNA sequence. Int J Syst Evol Microbiol 50, 1563-1589.
Felsenstein, J. (1989). PHYLIP - phylogeny inference package (version 3.2). Cladistics 5, 164-166.

Felsenstein, J. (2004). Inferring Phylogenies. Sunderland, MA: Sinauer Associates.

Fitch, W. M. \& Margoliash, E. (1967). Construction of phylogenetic trees. Science 155, 279-284.

Fritz, I. (2000). Das Bakterioplankton im Westlichen Mittelmeer. PhD thesis, Technical University Braunschweig. http://www.biblio.tu-bs. de/ediss/data/20000811a/20000811a.html (in German).

Gillis, M., De Ley, J. \& Cleene, M. (1970). The determination of molecular weight of bacterial genome DNA from renaturation rates. Eur J Biochem 12, 143-153.

Hines, B. \& Dyall-Smith, M. (2003). ARB for Mac OS X: phylogeny with finesse! http://www.microbiol.unimelb.edu.au/micro/staff/mds/ ARB_OSX/ARB_to_MacOSX.html

Höfle, M. G. (1998). Genotyping of bacterial isolates from the environment using low-molecular-weight RNA fingerprints. In Molecular Microbial Ecology Manual, pp. 1-23. Edited by A. D. L. Akkermans, J. D. van Elsas \& F. J. de Bruijn. Dordrecht: Kluwer Academic Publishers.

Jukes, T. H. \& Cantor, C. R. (1969). Evolution of protein molecules. In Mammalian Protein Metabolism, pp. 21-132. Edited by H. H. Munro. New York: Academic Press.

Li, Y., Kawamura, Y., Fujiwara, N., Naka, T., Liu, H., Huang, X., Kobayashi, K. \& Ezaki, T. (2004). Sphingomonas yabuuchiae sp. nov. and Brevundimonas nasdae sp. nov., isolated from the Russian space laboratory Mir. Int J Syst Evol Microbiol 54, 819-825.

Link, W., Dixkens, C., Singh, M., Schwall, M. \& Melchinger, A. E. (1995). Genetic diversity in European and Mediterranean faba bean germ plasm revealed by RAPD markers. Theor Appl Genet $\mathbf{9 0}$, 27-32.

Ludwig, W., Strunk, O., Westram, R. \& 29 other authors (2004). ARB, a software environment for sequence data. Nucleic Acids Res 32, 1363-1371.

Mergaert, J., Boley, A., Cnockaert, M. C., Muller, W. R. \& Swings, J. (2001). Identity and potential functions of heterotrophic bacterial isolates from a continuous-upflow fixed-bed reactor for denitrification of drinking water with bacterial polyester as source of carbon and electron donor. Syst Appl Microbiol 24, 303-310.

Segers, P., Vancanneyt, M., Pot, B., Torck, U., Hoste, B., Dewettinck, D., Falsen, E., Kersters, K. \& De Vos, P. (1994). Classification of Pseudomonas diminuta Leifson and Hugh 1954 and Pseudomonas vesicularis Büsing, Döll, and Freytag 1953 in Brevundimonas gen. nov. as Brevundimonas diminuta comb. nov. and Brevundimonas vesicularis comb. nov., respectively. Int J Syst Bacteriol 44, 499-510.

Smibert, R. M. \& Krieg, N. R. (1981). General characterization. In Manual of Methods for General Bacteriology, pp. 409-443. Edited by P. Gerhardt, R. G. E. Murray, R. N. Costilow, E. W. Nester, W. A. Wood, N. R. Krieg \& G. B. Phillips. Washington, DC: American Society for Microbiology.

Stahl, D. A., Key, R., Flesher, B. \& Smit, J. (1992). The phylogeny of marine and freshwater caulobacters reflects their habitat. $J$ Bacteriol 174, 2193-2198.

Van de Peer, Y. \& De Wachter, R. (1994). TREECON for Windows: a software package for the construction and drawing of evolutionary trees for the Microsoft Windows environment. Comput Appl Biosci 10, 569-570.

Wayne, L., Brenner, D., Colwell, R. \& 9 other authors (1987). Report of the ad hoc committee on reconciliation of approaches to bacterial systematics. Int J Syst Bacteriol 37, 463-464. 
Yokoyama, A., Miki, W., Izumida, H. \& Shizuri, Y. (1996). New trihydroxy-keto-carotenoids isolation from an astaxanthin-producing marine bacterium. Biosci Biotechnol Biochem 60, 200-203.
Ziemke, F., Brettar, I. \& Höfle, M. G. (1997). Stability and diversity of the genetic structure of a Shewanella putrefaciens population in the water column of the central Baltic. Aquat Microb Ecol 13, 63-74. 